\title{
Research on Community Public Affairs Management after "Removing Villages and Building Houses"
}

\author{
Jinmeng Liu \\ Zhejiang Agriculture and Forestry University, Hangzhou, China \\ Email: okljmok@gmail.com
}

How to cite this paper: Liu, J.M. (2019) Research on Community Public Affairs Management after "Removing Villages and Building Houses". Open Journal of Social Sciences, 7, 70-80.

https://doi.org/10.4236/jss.2019.78006

Received: July 11, 2019

Accepted: August 10, 2019

Published: August 13, 2019

Copyright $\odot 2019$ by author(s) and Scientific Research Publishing Inc. This work is licensed under the Creative Commons Attribution International License (CC BY 4.0).

http://creativecommons.org/licenses/by/4.0/

\begin{abstract}
In 2013, according to the opinions of Lin'an municipal government, the civil affairs bureau conducted a survey on the 11th neighborhood committee in the main urban area and carried out the work of removing villages and building houses. At that time, the 11 turnover neighborhood committees in Lin'an were actually run in accordance with the administrative villages since 2002, which were only nominally called the residents' committees. In August 2017, according to the instructions of the state council, Lin'an was officially designated as Hangzhou's administrative jurisdiction. In order to speed up the integration into the main urban area of Hangzhou, promote the internationalization of the city, solve the urban governance problems, and respond to the needs of the masses, a new batch of "remove villages and build houses" work began to be carried out in Lin'an district. With Lin'an withdraw after completion of work to make the city divided into districts, the acceleration of urban development, urban management needs more and more obvious, residents living environment, social services and so on various aspects of expected to improve, especially the villagers living in the city center area, use rural management way, farmer's way of life, do not coordinate with the rapid urbanization, the operation mode of the community of residents' desire for community, to accelerate the withdrawal village into the community. However, whether the public service capacity of various government departments can keep up with the pace of urbanization, and whether the connection between different departments is smooth and appropriate, are the questions we urgently need to know at present.
\end{abstract}

\section{Keywords}

Remove Villages and Build Houses, Public Affairs, Work Cohesion 


\section{Problem Posing}

"Remove villages and build houses" is an important way of rural urbanization. Since 2017, the government of Lin'an district has seized the historical opportunity of "withdrawing cities and establishing districts". In order to make up for the shortcomings of urban development, it "builds new cities and renovates old cities" to meet the needs of urbanization to some extent. However, there are some problems in this process, such as the asset quantification is not in place, and the shareholding system reform in some villages is not completed or not completely. It is not clear how to requisition collective land and there is no guarantee for the approval of building houses for farmers. There are some deficiencies in social security endowment insurance. Urban and rural areas are staggered, and management is not in place. Administrative villages and urban communities are staggered, and rural villagers and urban residents live together. Urban villages lack unified planning and scientific management, and infrastructure construction is weak. In terms of household registration management, there is inconsistency between the registered residence and the actual residence, and no one manages the residence.

In terms of community public service research, current scholars mainly focus on the current situation and existing problems of public service supply, as well as the mechanism and mode of public service supply. Scholars believe that the current supply of public cultural services in "removing villages and building houses" communities generally has problems such as insufficient total supply, imbalance between supply and demand, low level of public service specialization and service quality, and low efficiency of supply. Liang yihui [1] pointed out in the survey of "removing villages and building houses" communities in the pearl river delta region that there are problems such as insufficient investment in basic public services, imbalance between urban and rural areas, disparity between regions, disparity between different groups, and lack of mandatory and normative government investment in public services. Wan xuefen [2], taking Xihu district of Hangzhou city as a case study, pointed out that there were problems of low efficiency of public service supply and lack of independent supply in "removing villages and building houses" communities at present. According to the current problem, the scholars think that improve the diversification of public service supply mechanism is the only way, through the power of market, society, and residents to enrich the content of public service and quantity, by means of competition to provide quality, Zhu Minqing [3] argues that " $i$. house" with the residents to participate in public service supply mechanism innovation are inseparable, must cultivate the citizen participation consciousness, guide the residents to participate in public service supply. Huang chunlei believes that the innovative public service supply mode can be used to flexibly use franchising, financial subsidies, government purchase of services and other means to attract investment from private capital and social organizations and alleviate the gap in public service supply. 
On the basis of scholars' research, this paper focuses on the guarantee and ability of community public services after the "removal of villages and building houses", explores the shortcomings and gives some opinions and Suggestions.

\section{Concept and Classification of Community Public Service}

Public service is the core concept of public administration and government reform in the 21st century, including strengthening the construction of public facilities in urban and rural areas, developing public undertakings such as education, science and technology, culture, health and sports, and providing guarantee for the public to participate in social, economic, political and cultural activities. Public services are based on cooperation, including strengthening the construction of urban and rural public facilities, emphasizing the service nature of the government and the rights of citizens.

Community public service limits the scope of services within the community, emphasizing the role of community as a grass-roots management organization of residents' autonomy in providing public services for residents. The main body is still the residents, but the main body of service is the basic unit of community.

Public service can be divided into basic public service, economic public service, public security service and social public service according to its content and form. Basic public services refer to those basic services that citizens and their organizations need to engage in production, life, development, entertainment and other activities through intervention of state power or input of public resources, such as providing water, electricity and gas, transportation and communication infrastructure, post and telecommunications and meteorological services. Economic public service refers to various services provided by citizens and their organizations, namely enterprises, to engage in economic development activities through state power intervention or public resource input, such as science and technology promotion, consulting services and policy credit. Public security service refers to the security service provided for citizens through state power intervention or public resource input, such as military, police and fire protection services. Social public service refers to the service provided to meet the direct needs of citizens' social development activities through state power intervention or public resource input. The fields of social development include education, scientific popularization, medical and health care, social security and environmental protection. Social public service is to meet the direct social needs such as citizens' survival, life and development, such as public education, public medical treatment and public social welfare.

\section{Relevant Data and Problem Analysis}

Establishing residences Lin'an area "plays an important role in the urbanization wave, although in recent years" i. house in the boom of other cities in China have started to work, and even the construction of many cities formed its own models and basic prototypes, for Lin'an, however, is still a reference to the 
reform mode of others, the separation of political and economic management of the rural collective economic organizations way though built in most villages and communities have to paraphrase, however, is in line with the actual development situation is still questionable. In addition, due to the professional knowledge structure and technical limitations, this paper only analyzes the community public affairs management of "removing villages and building houses" to promote the optimization and improvement of management. The following analysis is made:

Since the approval of the reform document of "removing villages and building houses", various villages and old communities in Lin'an district have carried out large-scale reconstruction. However, are residents aware of these works? Before and after "removing villages and building houses", are the residents really protected by the public affairs management? What factors are influencing residents' satisfaction? These should be Lin'an district government and each responsible street should know the important content. Through the above analysis, the area of Lin'an "withdraw village to build a house" have a preliminary understanding, in order to further understand the Lin'an area "withdraw village to build a house" the present situation of the public affairs management, this article in Lin'an area reconstruction community within the scope of random sampling investigation method, the "withdraw village to build a house" public affairs management satisfaction survey research in Lin'an people's heart. A total of 531,500 respondents are involved in this paper. We determine the number of sample elements according to Scheaffer formula:

$$
N^{*}=\frac{N}{(N-1) \delta^{2}+1}
$$

In the above formula, $N^{*}$ is the number of sample elements, $N$ is the research object, i.e. the total population of the Lin'an area is surveyed, $\delta$ sampling error is set to 0.06 , thus

$$
N^{*}=\frac{531500}{(531500-1) \times 0.06^{2}+1}
$$

the number of sampling elements in the Lin'an area is 278 people. The survey adopts the method of questionnaire and structured interview. The contents of the questionnaire mainly include residents' overall satisfaction with the public affairs management of "removing villages and building houses", their satisfaction with the supporting facilities in the community, their satisfaction with the safety and security work and basic information. According to the principle of social statistics, the final number of questionnaires should be more than the number of people calculated by the formula. In this study, a total of 337 questionnaires were issued, 11 of which were invalid and 10 were invalid, thus 316 valid questionnaires were obtained. Therefore, the following analysis is based on 316 questionnaires.

The Basic information of interviewees is shown in Table 1. 
Table 1. Basic information of interviewees.

\begin{tabular}{|c|c|c|c|}
\hline & category & frequency & proportion \\
\hline \multirow{2}{*}{ gender } & $\operatorname{man}$ & 145 & $45.9 \%$ \\
\hline & female & 171 & $54.1 \%$ \\
\hline \multirow{5}{*}{ age } & age under 18years & 4 & $0.04 \%$ \\
\hline & 18 to 25 years old & 87 & $1.3 \%$ \\
\hline & 26 to 35 years old & 72 & $27.5 \%$ \\
\hline & 36 to 45 years old & 52 & $22.8 \%$ \\
\hline & above 46 years of age & 99 & $16.5 \%$ \\
\hline \multirow{3}{*}{ The degree of education } & High school and below & 43 & $31.3 \%$ \\
\hline & Junior college and undergraduate & 97 & $30.7 \%$ \\
\hline & Master degree or above & 182 & $57.6 \%$ \\
\hline \multirow{7}{*}{ Professional types } & Civil servants and public officers & 37 & $11.7 \%$ \\
\hline & & 43 & $46.8 \%$ \\
\hline & Company employees & 55 & $17.4 \%$ \\
\hline & Individual business & 69 & $21.8 \%$ \\
\hline & retirees & 103 & $32.6 \%$ \\
\hline & students & 26 & $8.2 \%$ \\
\hline & others & 20 & $6.3 \%$ \\
\hline
\end{tabular}

It can be clearly seen from the table that the respondents involved in this questionnaire survey are of different ages and occupations, and the gender of men and women is generally balanced. It is known that the questionnaire has certain reliability and validity.

It can be seen from Table 1 that the gender, age and other social attribute structures of interviewees are relatively reasonable. Female respondents outnumbered male respondents by $8.2 \%$; The age group was mainly 18 - 35 years old, accounting for $50.3 \%$ of the total sample. The respondents were mature and capable of independent thinking and discrimination. $88.3 \%$ of the respondents have a college degree or above, indicating that the respondents have a high level of knowledge and have basic ability to identify and judge the contents of the questionnaire. The respondents covered different occupations, mainly retirees. Therefore, it can be considered that this questionnaire survey shows different groups' different cognition of "removing villages and building houses" in Lin'an from different genders, ages, knowledge structures and industries, and lays a good mass foundation for this study.

According to field visits and literature review, it is found that the management practice mode of "removing villages and building houses" in Lin'an district has the following characteristics:

\subsection{Former Village Collective Economy Organization Develops Unbalanced}

First, according to the annual report of 2012, the development of village collec- 
tive economy is extremely unbalanced. In 2012, the highest income of village collective economy in xinmin village was 9.75 million yuan (excluding subsidy income), while the lowest income was zero. There are 16 villages with incomes of more than 1 million yuan, including 5 villages in jincheng street, 5 villages in qingshanhu street, 3 villages in yuqian town, and 3 villages in linglong street, jinnan street and qingliang peak town. There are 33 villages without economic income, accounting for $11.07 \%$ of the total number of villages. There are 91 villages under 100,000 yuan, accounting for $30.53 \%$ of the total number of villages.

Second, the village collective economic growth lack of aftereffect. Most of the village-level collective economy accumulation in the implementation of the rural reform has been run out, there is no collective resources, collective enterprise, collective income "and" shell " 3 without" village village phenomenon is more prominent, such as the island stone town villages trees all the subcontract to the home, develop the collective economy is faced with "from scratch" awkward. Urban villages, at the same time, in addition to the central village, garden village, town, village, has a stable source of property economy, most of the village collective economy has stability, income and income channels to atrophy, such as forest land contract, lease as the main part of the income abundant mountain village, often take when operating period is longer than the close to buyout lease model, although increased the village collective income in the short term, but in the long term lack developing power, seriously restricts the development of village collective economy.

\subsection{The People Are Generally Satisfied with the Management of Public Affairs}

The analysis of field research data shows that the respondents are basically satisfied, satisfied and very satisfied with the public affairs management of "removing villages and building houses" in Lin'an district. $96.1 \%$ of the respondents hold a favorable attitude towards municipal infrastructure (such as construction and management of roads, street lamps, environmental sanitation, greening, beautification, power supply and water supply, etc.). $92.8 \%$ of the respondents recognized the service of newly established public servants in the community; $91.4 \%$ of the respondents believed that community medical services were basically acceptable. $96.3 \%$ of respondents approved the employment security situation; $92.7 \%$ of the respondents approved of the security situation in the community (Table 2).

In order to further explore the current management status of public affairs in Lin'an district "removing villages and building houses", the public rating on public affairs management of "removing villages and building houses" in Lin'an district is presented now, and the influencing factors include municipal infrastructure, public servant service, community medical service, employment security, public security and safety. Will be public satisfaction rating is set to 5, 4, 3, 2, 1, five indicators, using multiple independent sample test of Kruskal Wallis inspection, inspection based on different game perception of municipal 
Table 2. The frequency of the respondents' recognition of the public affairs management of "removing villages and building houses".

\begin{tabular}{cccccc}
\hline $\begin{array}{c}\text { Recognition } \\
\text { (cumulative percentage) }\end{array}$ & $\begin{array}{c}\text { Municipal } \\
\text { infrastructure }\end{array}$ & $\begin{array}{c}\text { Public } \\
\text { service }\end{array}$ & $\begin{array}{c}\text { Community } \\
\text { health service }\end{array}$ & $\begin{array}{c}\text { Employment } \\
\text { security }\end{array}$ & $\begin{array}{c}\text { Security } \\
\text { situation }\end{array}$ \\
\hline great satisfaction & 9.1 & 10.0 & 9.7 & 9.3 & 8.2 \\
satisfaction & 53.2 & 54.3 & 47.8 & 46.2 & 45.4 \\
basic satisfaction & 96.1 & 92.8 & 91.4 & 96.3 & 92.7 \\
not satisfied with & 19.3 & 19.5 & 18.6 & 10.2 & 8.9 \\
dissatisfied & 3.2 & 2.1 & 0.7 & 7.9 & 2.4 \\
\hline
\end{tabular}

infrastructure, public office services, community health services, job security, public order security situation whether have significant difference, through Kruskal Wallis test its significant P-value is less than 0.05 , five groups have significant difference, affects the area of Lin'an "Remove villages and build houses" overall satisfaction score, deserves further research (Table 3).

\section{The Problems in the Public Administration of "Removing Villages and Building Houses"}

\subsection{Neighborhood Committee Reform Management Is Still Not Ideal}

In Zhejiang province in 2002 to achieve "civilized city", Lin'an area 11 village conducted i. house, yet these villages, in fact, only a "flip" ${ }^{\text {, }}$ nominally, the residents committee is essentially in accordance with the administrative villages in the running, and so over the years, 11 administrative villages properties of residents' committees are not fundamental change. First, the way of organization and management is not included in community management. Second, the status of residents has not been changed. For example, policies such as compensation for accidents and social insurance are still implemented according to the original status standards. Third, all kinds of village-level creation projects cannot be carried out, and governments at all levels cannot participate in rural project subsidy policies, such as the construction of cultural halls. "Not in house, not farmers, therefore," the current situation of the impact on the development of 11 neighborhood committees and the fundamental interests of the residents, NPC delegates called for promoting the job every year, until after Lin'an "removed from the city divided into districts" in 2018, Lin'an district government issued a formal document that made " $\mathrm{i}$. house" to carry out, according to the current research results, however, residents' committees in the restructuring is still not complete, many residents don't even know their community didn't change.

\subsection{It Is Difficult to Unify the Urban Management System}

The first is regulatory confusion. In the main urban area, 11 residents' committees and some urban villages, such as Huilong village, Pingshan village and

${ }^{1}$ Note: only the name has changed, its internal operation mode and structure are the same as the original village. 
Table 3. Kruskal-Wallis test table.

\begin{tabular}{cccccc}
\hline \multicolumn{6}{c}{ Test statistics $^{\mathrm{a}, \mathrm{b}}$} \\
\hline & $\begin{array}{c}\text { Municipal } \\
\text { infrastructure }\end{array}$ & $\begin{array}{c}\text { Public } \\
\text { service }\end{array}$ & $\begin{array}{c}\text { Community } \\
\text { health service }\end{array}$ & $\begin{array}{c}\text { Employment } \\
\text { security }\end{array}$ & $\begin{array}{c}\text { Security } \\
\text { situation }\end{array}$ \\
\hline chi-square & 51.633 & 48.751 & 63.238 & 57.743 & 56.594 \\
df & 4 & 4 & 4 & 4 & 4 \\
Asymptotic significance & 0.000 & 0.000 & 0.000 & 0.000 & 0.000 \\
\hline
\end{tabular}

${ }^{\mathrm{a}}$ Kruskal Wallis test; ${ }^{\mathrm{b}}$ Grouping variable: please score the overall satisfaction of public affairs management work of "withdrawing villages and building houses" in Lin'an district (full mark: 5).

Nishanwan village, are intermingled in the community. The community management is mixed with the residential and village management in the same area, and the phenomenon of the same residence and different management appears. At the same time, there are still unclear phenomena in the management of functional departments, such as urban management, traffic police, police stations, market supervision, environmental protection, etc., which are not managed according to the community division, leading to the difficulty in unifying and coordinating the community work.

The second is confusion. Xinminli, Jinqiao, maxi and Xishu have both community and neighborhood committees, so it is difficult to distinguish between community and neighborhood committees.

The third is planning confusion. Because communities, neighborhood committees and villages coexist in the region, urban planning, urban management and construction of public facilities cannot be unified planning and management. Many areas are neither urban nor rural in their planning. It is mainly reflected in untidy buildings, urban buildings and rural buildings. Secondly, people's urban and rural household registration status is not clear, and the management of household registration lacks specific and clear documentation.

Finally, city access is limited. With the development of Qingshanhu science and technology city, the residential community in Qingshanhu street has an increasing number of residents, and the migrant population is increasing year by year. Landless farmers are gradually entering apartment buildings and other phenomena. Due to the lack of community construction at present, it is more difficult to manage the agglomeration population in residential communities.

\subsection{Urban Community Services Are Lagging Behind}

Lin'an district has many problems such as narrow development space, weak economic foundation, slow development of traffic information network, insufficient urban infrastructure construction, low urbanization level, unbalanced urban labor force distribution and weak driving force of urban communities. After the "removal of villages and building houses", there are problems in the connection between the work undertaken by the relevant departments of the government and the work to be undertaken. After the original administrative village 
became the neighborhood committee, the public services of various urban communities were not perfectly connected.

Lin'an district currently has a total of 16 communities, compared with the surrounding counties and urban areas: 170 in Xiaoshan district (excluding 8 in Dajiang east), 165 in Yuhang district, 28 in Fuyang district, 18 in Tonglu county, 27 in Jiande city and 12 in Chun'an. First, some communities in the main urban area are overloaded with scale management, such as Jincheng street Wuxuli community and Wenchangge community. After removing villages (residences) into the community, the community management of the original saturated load is further increased. Second, some urban villages, with the development of stock system quantification, land expropriation and demolition, and the needs of urban development, have been able to remove villages and build communities. For example, Huilong village, Jinbei street, is located in the center of the city. It is necessary to improve the urban management level and residents' quality of life through community management.

\section{Counter Measures and Suggestions}

\subsection{Completely Change the Operation Mode of Village Committee}

In the reform of administrative system, once the village becomes the urban neighborhood committee, its operation mode and administrative system should be changed accordingly. Including residents in the household registration management, medical insurance and other aspects should be correspondingly connected with urban communities. Secondly, in terms of water conservancy, roads and municipal administration, we should also get rid of the management of the original village and come under the unified planning and management of the municipal government.

\subsection{The Municipal Government Should Unify the Planning and Management of New Communities}

After the "removal of the village", many of the village's public affairs management aspects have undergone major changes. Especially in the administrative system, such as the village fund integration and the village collective assets that were originally under the responsibility of the village committee, it should now be organized and managed by the village collective economic committee. In addition to economic affairs, all other matters must be managed by the existing residents committee. That is to say, the economy and other affairs should be managed separately to achieve the "political and economic separation" model. So really get rid of the problem of the original management confusion.

\subsection{Strengthening the Convergence of Community Services}

We know that the original community has changed from a village to an urban community. The entire village has not only undergone tremendous changes in the administrative system, but the lifestyle of the original villagers must have 
undergone tremendous changes. Residents were transformed from the original villagers, and public affairs were also responsible for the transformation of the village committee into the city neighborhood committee. The city neighborhood committee is directly affiliated to each street and ultimately belongs to the municipal government. Therefore, many of the original public affairs such as road planning, street lighting, water conservancy and other aspects need to be docked and connected with the existing resident committee. According to the survey results, the biggest difficulty encountered by the staff of the municipal government is that the work of each department cannot be smoothly connected with the person in charge of the original work. Therefore, in this regard, it is still necessary to increase the intensity to adapt and dock.

Second, we need to innovate the mechanism for providing public services. The author found in the survey, in the implementation of "the home village changed" community, even in the early days of government fiscal situation, has the strength of the collective economic groups also invested a lot of money supporting infrastructure construction and management and park, education, health care, pension, health and other public service facilities, it can improve in the community residents of public interests at the same time, also for the collective economy considerable return on investment and return. This is give us beneficial enlightenment, collective economy with urban public service supply of potential energy and the superiority, the collective economic organizations are more likely to understand community needs, focus on community development, industrial layout and space to grow up and pursue long-term economic benefits, under the policy incentives, such as land, finance and tax, can realize win-win situation of economic and social benefits.

\section{Conclusions}

Urban and rural symbiosis is not only an idealization and gradual process, but also a process of policy practice and community planning. The integration of urban and rural areas is not only the embedded background of Lin'an's changes and development, but also the process of how the two internal forces of "city" and "township" go hand in hand and multi-integration in the process of shaping Lin'an's political, economic, cultural and social outlook in practice. Lin'an community transformation not only need to set up "to the city to promote township" and "hometown to promote city" two "urban-rural integration" concept, the transformation needs to be in the correct analysis and treatment on the basis of the relationship between urban and rural areas, is a kind of "government intervention and social participation, domination" of the system and mechanism, also in the organization, participation, resources and incentive supervision on specific mechanisms including systematic construction.

In addition, although Lin'an has completed the overall planning of "removing villages and building houses", the connection between various departments in public affairs management still needs to be kept close. 
We must clarify the boundaries of government responsibilities. In the early stage of the implementation of "village housing reform", most of the activities such as infrastructure reconstruction and community construction were organized and completed by the original village committees, and the government responsibility was absent. With the rapid growth of the number of "village to residence" communities and the rise of a large number of urban villages, the problem of the boundary of government responsibility for public service supply before, during and after urban transformation gradually emerges. Therefore, the powers and responsibilities of the government must be clear and clear.

Finally, I would like to say that due to the limited knowledge I have learned, I am still continually researching and developing this topic. Because this work has been officially launched since 2017, the problems currently faced are still constantly exposed, so this article the issues involved may still be insufficiently comprehensive and will continue to be followed up in future research.

\section{Conflicts of Interest}

The author declares no conflicts of interest regarding the publication of this paper.

\section{References}

[1] Liang, Y.H. (2013) The Status Quo and Influence of Village Relocation to Basic Public Services from the Perspective of Community Governance-Based on a Survey of the Pearl River Delta. Journal of Yunnan University of Administration, 15, 115-117.

[2] Wan, X.F. (2007) Exploration on the Autonomous Mode of "Village to Residence" Community in Transition Period-Taking Hangzhou Xihu District as an Example. Journal of Party School of Hangzhou Municipal Party Committee, 2, 28-31.

[3] Zhu, M.Q. (2014) Innovation of Public Service Supply Mechanism of "Village to Residence" Community. Open Herald, 6, 41-44. 